\author{
BARBARA MAŁGORZATA KAŁDON \\ Uniwersytet Kardynała Stefana Wyszyńskiego \\ $w$ Warszawie
}

\title{
CHARAKTERYSTYKA SPRAW O PRZESTĘPSTWA PRZECIWKO RODZINIE
}

\section{CASES AGAINST FAMILY - CHARACTERISTIC}

\section{Streszczenie}

Przemoc domowa jest często ukrywana i trafia do organów ścigania oraz organizacji służącym im pomocą tylko w wyjątkowo poważnych okolicznościach. Jest to zjawisko trudne w ocenie, gdyż nie wszystkie przypadki są znane ze statystyki skazań, czy z przeprowadzanych badań w tym temacie i w związku z tym mogą nie do końca odpowiadać rzeczywistości.

Skala przemocy jest z pewnością większą, niż wskazują na to dane statystyczne, $\mathrm{z}$ tego powodu, iż ofiary mają liczne bariery w przyznawaniu się co do doświadczonej krzywdy, często usprawiedliwiają one zachowanie sprawcy, obwiniając siebie za zaistniałą sytuację, a także nie są świadome swoich praw i nie umieją się stosownie odnaleźć w sytuacji, w której się znalazły.

Słowa kluczowe: znęcanie się, rodzina

\section{Summary}

The home violence is often hidden and is finding his way to law enforcement agencies and the organization for housemaids for them with help only in exceptionally serious circumstances. This difficult pheno- 
menon is in the evaluation, because not all cases are well-known for the statistics of convictions, whether in this subject and therefore reality can not entirely be examined on conducted examinations.

The scale of the violence is certainly greater than, they show statistical data to it, for this reason, that victims have numerous barriers in admitting regarding experienced harm, they often justify behaving for the perpetrator, blaming themselves for the existing situation, as well as aren't conscious of their laws and cannot appropriately be found in the situation in which they were.

Key words: victimization, family

\section{WPROWADZENIE}

Prezentowany artykuł ma charakter empiryczny. Miejscem moich badań był Sąd Rejonowy w Stalowej Woli. Materiałem badawczym były akta sądowe (grupa $100 \mathrm{akt}$ ) z lat 1997-2010 (do 30.06.), dotyczące art. $207 \S 1$ k.k. (przestępstwa znęcania się). Kryterium ich doboru była kwalifikacja sprawy oraz stwierdzenie, że ofiarą było dziecko. Akta były wybierane w drodze losowej przez pracowników sekretariatu Wydziału Karnego. Badania przeprowadzono w oparciu o kwestionariusz ankiety do analizy akt sądowych.

\section{CHARAKTERYSTYKA OGÓLNA}

Poniżej zostały ukazane zbiorcze wyniki dotyczące: sumy wpływu spraw z powyżej wspomnianego okresu czasu w Wydziale II Karnym Sądu Rejonowego w Stalowej Woli z uwzględnieniem liczby spraw z małoletnimi pokrzywdzonymi oraz sumą stwierdzonych przypadków małoletnich pokrzywdzonych w przeprowadzonych postępowaniach. 
Tabela 1. Sprawy z art. $207 \S 1$ k.k. rozpatrywane przez Sąd Rejonowy w Stalowej Woli.

\begin{tabular}{|c|c|c|c|c|}
\hline \multirow{2}{*}{ Rok } & \multicolumn{2}{|c|}{ Wpływ spraw: w tym } & \multirow{2}{*}{$\begin{array}{l}\text { Liczba spraw } \\
\text { z pokrz. } \\
\text { małoletnimi }\end{array}$} & \multirow{2}{*}{$\begin{array}{c}\text { Liczba } \\
\text { małoletnich } \\
\text { stwierdzonych }\end{array}$} \\
\hline & Ogółem & Z art. $207 \S 1$ k.k. & & \\
\hline 1997 & 597 & 68 & 5 & 8 \\
\hline 1998 & 632 & 88 & 17 & 29 \\
\hline 1999 & 590 & 73 & 18 & 32 \\
\hline 2000 & 687 & 67 & 17 & 34 \\
\hline 2001 & 1148 & 57 & 12 & 20 \\
\hline 2002 & 1459 & 102 & 14 & 26 \\
\hline 2003 & 1593 & 97 & 24 & 41 \\
\hline 2004 & 1785 & 86 & 26 & 57 \\
\hline 2005 & 1478 & 63 & 19 & 38 \\
\hline 2006 & 1331 & 33 & 8 & 15 \\
\hline 2007 & 1392 & 38 & 6 & 9 \\
\hline 2008 & 1335 & 40 & 10 & 18 \\
\hline 2009 & 1446 & 27 & 5 & 9 \\
\hline $\begin{array}{c}2010 \text { do } \\
30.06 .2010\end{array}$ & 540 & 14 & 3 & 5 \\
\hline Suma: & 16013 & 853 & 184 & 341 \\
\hline
\end{tabular}

W latach 1997-2005 sprawy z art. 207§ 1 k.k. na terenie Wydziału II Karnego Sądu Rejonowego w Stalowej Woli utrzymywały się na poziomie od 57 w 2001 roku do 102 w 2002. Od roku 2006 do 2010 (30.06.) zaobserwowano znaczny ich spadek. Najwięcej spraw z pokrzywdzonymi małoletnimi było w latach 2003-2004, a liczba stwierdzonych pokrzywdzonych małoletnich była największa w latach 1998- 2005, ze spadkiem w 2001 roku. 


\section{OFIARY PRZEMOCY W RODZINIE}

Dla dokładnego scharakteryzowania spraw dotyczących przestępstwa znęcania się nad członkami rodziny, niezbędne było ustalenie na początku liczby ofiar z tego zakresu.

Tabela 2. Liczba ofiar przemocy w rodzinie

\begin{tabular}{|l|c|c|}
\hline \multicolumn{1}{|c|}{ Liczba ofiar przemocy } & $\begin{array}{c}\text { Liczba ofiar } \\
\mathrm{N}=257\end{array}$ & $\%$ \\
\hline Liczba ofiar dorosłych & 108 & 42 \\
\hline Liczba ofiar dzieci & 149 & 58 \\
\hline
\end{tabular}

W 100 przebadanych aktach sądowych - czyli odnośnie 100 sprawców stwierdzono 257 ofiar przemocy domowej z art. 207 § 1 k.k. po stronie zarówno dorosłych, jak i dzieci.

Tabela 3. Ofiary przemocy.

\begin{tabular}{|l|c|c|}
\hline \multicolumn{1}{|c|}{ Ofiary przemocy } & $\begin{array}{c}\text { Liczba spraw } \\
\mathrm{N}=100\end{array}$ & $\%$ \\
\hline Dzieci & 32 & 32 \\
\hline Dzieci i dorośli & 68 & 68 \\
\hline
\end{tabular}

Jak wynika z powyższych danych, w przeanalizowanych sprawach były 32 sprawy odnoszace się wyłącznie do małoletnich pokrzywdzonych, zaś w pozostałej większości przebadanych akt pokrzywdzonymi były zarówno dzieci, jak i osoby dorosłe. 
Tabela 4. Płeć ofiar przemocy domowej.

\begin{tabular}{|l|c|c|c|c|}
\hline \multirow{2}{*}{ Płeć } & \multicolumn{4}{|c|}{ Wiek ofiary } \\
\cline { 2 - 5 } & \multicolumn{2}{|c|}{ Małoletnie dzieci } & \multicolumn{2}{c|}{ Dorośli } \\
\cline { 2 - 5 } & $\mathrm{N}=149$ & $\%$ & $\mathrm{~N}=108$ & $\%$ \\
\hline Kobiety / dziewczynki & 70 & 47,0 & 86 & 79,6 \\
\hline Mężczyźni / chłopcy & 75 & 50,3 & 22 & 20,4 \\
\hline Brak danych & 4 & 2,7 & - & - \\
\hline
\end{tabular}

Wśród ofiar, którymi są dzieci odsetek dziewcząt i chłopców jest bardzo zbliżony. Czyli sprawcy równie często atakują dziewczynki i chłopców. W przypadku dorosłych wśród ofiar widoczna jest zdecydowana przewaga kobiet.

Wykres 1. Płeć ofiar przemocy domowej.

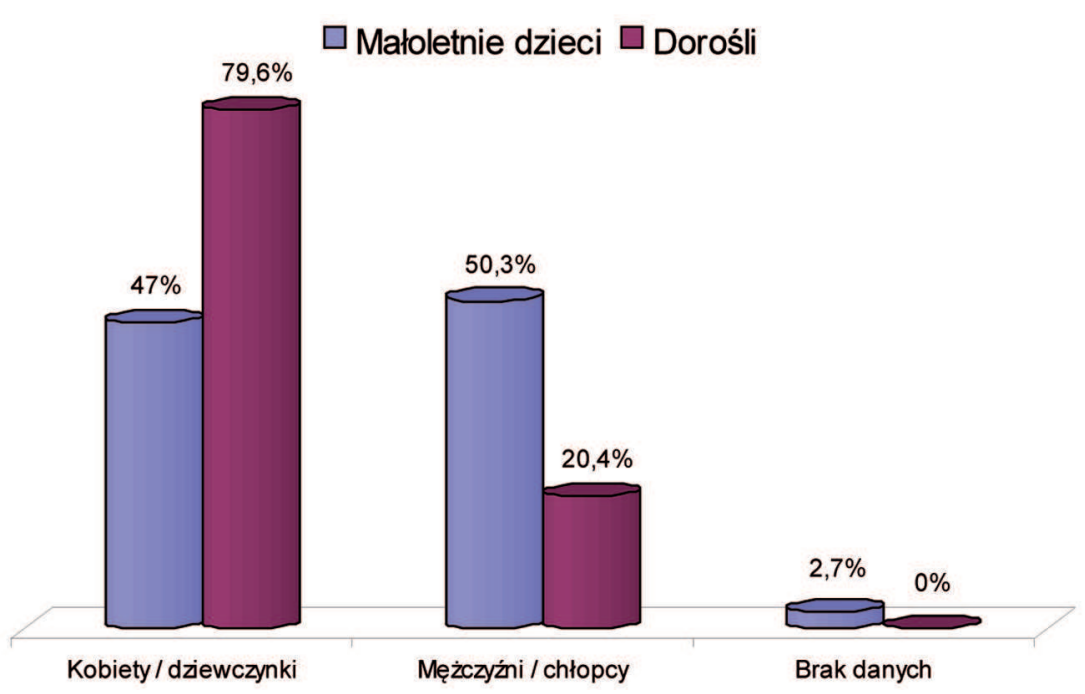


Tabela 5. Liczba ofiar przemocy w rodzinie sprawcy.

\begin{tabular}{|l|c|}
\hline \multicolumn{1}{|c|}{ Liczba ofiar przemocy w rodzinie sprawcy } & $\begin{array}{c}\text { Liczba ofiar } \\
\text { N }=257\end{array}$ \\
\hline Jedna ofiara w rodzinie & 77 \\
\hline Dwie ofiary w rodzinie & 89 \\
\hline Trzy ofiary w rodzinie & 64 \\
\hline Cztery ofiary w rodzinie & 20 \\
\hline Pięć ofiar w rodzinie & 7 \\
\hline
\end{tabular}

W przebadanych sprawach stwierdzono, iż przemoc domowa najczęściej dotyczyła rodzin, w których występowały dwie ofiary. Najmniejszy odsetek stanowiły zaś rodziny z piątką ofiar.

Tabela 6. Liczba ofiar - niepełnoletnich dzieci w rodzinie sprawcy.

\begin{tabular}{|l|c|c|}
\hline \multicolumn{1}{|c|}{$\begin{array}{c}\text { Liczba ofiar - niepełnoletnich dzieci } \\
\text { w rodzinie sprawcy }\end{array}$} & $\begin{array}{c}\text { Liczba spraw } \\
\mathrm{N}=100\end{array}$ & $\%$ \\
\hline Jedno dziecko & 65 & 65 \\
\hline Dwoje dzieci & 25 & 25 \\
\hline Troje dzieci & 6 & 6 \\
\hline Czworo dzieci & 4 & 4 \\
\hline
\end{tabular}

Jak wynika z analizy akt, największy odsetek wśród ofiar - niepełnoletnich dzieci w rodzinie sprawcy stanowiły rodziny z jednym dzieckiem, a w dalszej kolejności rodziny z dwójką dzieci. Najmniej przypadków znęcania się było w rodzinach, w których przemoc odnosiła się do 4 dzieci. 
Wykres 2. Liczba ofiar - niepełnoletnich dzieci w rodzinie sprawcy.

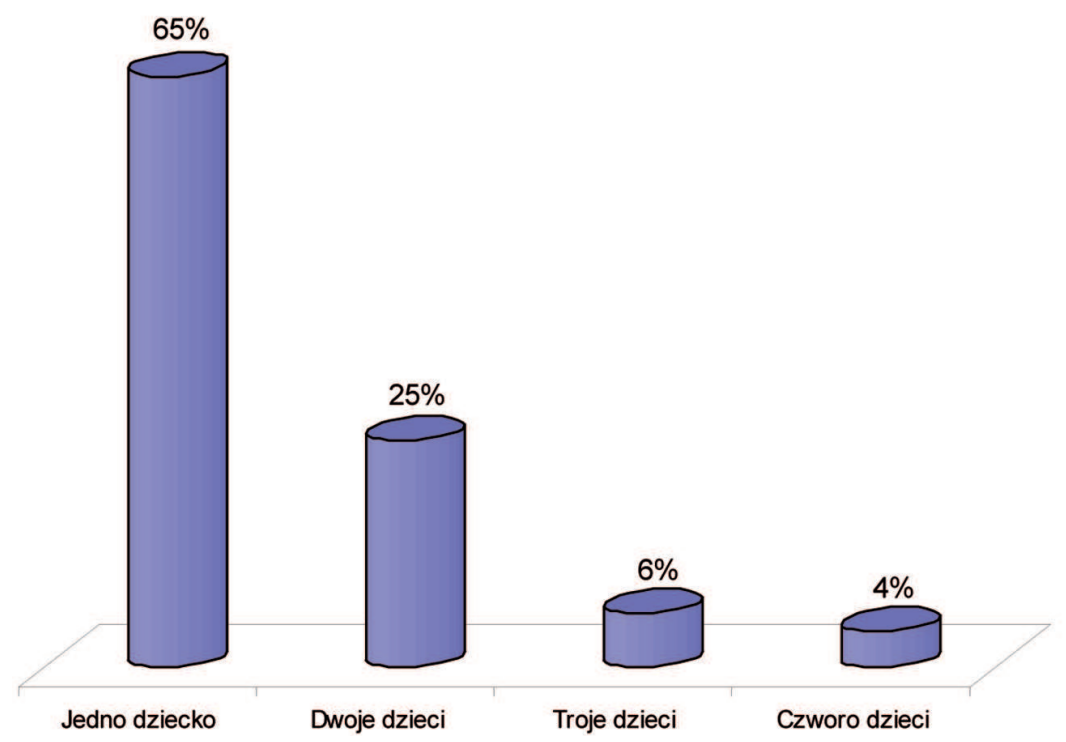

Tabela 7. Ofiary przemocy domowej w rodzinie sprawcy.

\begin{tabular}{|l|c|c|}
\hline \multicolumn{1}{|c|}{$\begin{array}{c}\text { Ofiary przemocy domowej } \\
\text { w rodzinie sprawcy }\end{array}$} & $\begin{array}{c}\text { Liczba spraw } \\
\mathrm{N}=100\end{array}$ & $\%$ \\
\hline Tylko niepełnoletnie dziecko/dzieci & 32 & 32 \\
\hline Matka, niepełnoletnie dziecko / dzieci & 52 & 52 \\
\hline $\begin{array}{l}\text { Matka, niepełnoletnie dziecko / dzieci } \\
\text { i inna osoba dorosła }\end{array}$ & 1 & 8 \\
\hline $\begin{array}{l}\text { Niepełnoletnie dziecko / dzieci i inna } \\
\text { osoba / osoby dorosłe }\end{array}$ & 8 & 7 \\
\hline $\begin{array}{l}\text { Matka, niepełnoletnie dziecko / dzieci, } \\
\text { pełnoletnie dziecko / dzieci }\end{array}$ & 7 & 1 \\
\hline
\end{tabular}

W przebadanych sprawach najczęściej ofiarą przemocy domowej w rodzinie sprawcy była jego żona oraz niepełnoletnie dziecko/ dzieci, przy 
czym dziecko/ dzieci występowały głównie wtedy, gdy miała miejsce przemoc wobec matki. W 32 sprawach ofiarami przemocy domowej były tylko małoletnie dzieci, a pozostałe kategorie stanowiły nieznaczny odsetek.

Tabela 8. Pokrewieństwo sprawcy przemocy w stosunku do dziecka - ofiary przemocy domowej.

\begin{tabular}{|l|c|c|}
\hline Kim jest sprawca w stosunku do ofiary & $\begin{array}{c}\text { Liczba ofiar } \\
\text {-dziecka? }\end{array}$ & $\begin{array}{c}\% \\
\text { niepełnoletnich } \\
\text { N }=149\end{array}$ \\
\hline Ojciec & 142 & 95,3 \\
\hline Brat & 3 & 2,0 \\
\hline Ojczym & 2 & 1,3 \\
\hline Bratanek & 1 & 0,7 \\
\hline Dziadek & 1 & 0,7 \\
\hline
\end{tabular}

W znacznie przeważającej części przebadanych spraw sprawcą przemocy względem dziecka był jego ojciec. W pojedynczych sprawach spotkano w charakterze sprawcy w tej kategorii - brata, ojczyma, bratanka/ siostrzeńca oraz dziadka.

Tabela 9. Pokrewieństwo sprawcy przemocy w stosunku do osoby dorosłej - ofiary przemocy domowej.

\begin{tabular}{|l|c|c|}
\hline \multicolumn{1}{|c|}{$\begin{array}{c}\text { Kim jest sprawca w stosunku do } \\
\text { ofiary dorosłej? }\end{array}$} & $\begin{array}{c}\text { Liczba ofiar } \\
\text { pełnoletnich } \\
\mathrm{N}=108\end{array}$ & $\%$ \\
\hline Mąż & 65 & 60,2 \\
\hline Ojciec & 21 & 19,4 \\
\hline Dziecko & 9 & 8,3 \\
\hline Były Mąż & 6 & 5,6 \\
\hline Brat & 3 & 2,8 \\
\hline Konkubent & 3 & 2,8 \\
\hline Wnuk & 1 & 0,9 \\
\hline
\end{tabular}


W większości przebadanych akt sprawcą wobec ofiary dorosłej był mąż. Znikomy procent dotyczył wnuka, konkubenta, brata czy byłego męża.

Wykres 3. Pokrewieństwo sprawcy przemocy w stosunku do osoby pełnoletniej - ofiary przemocy domowej.

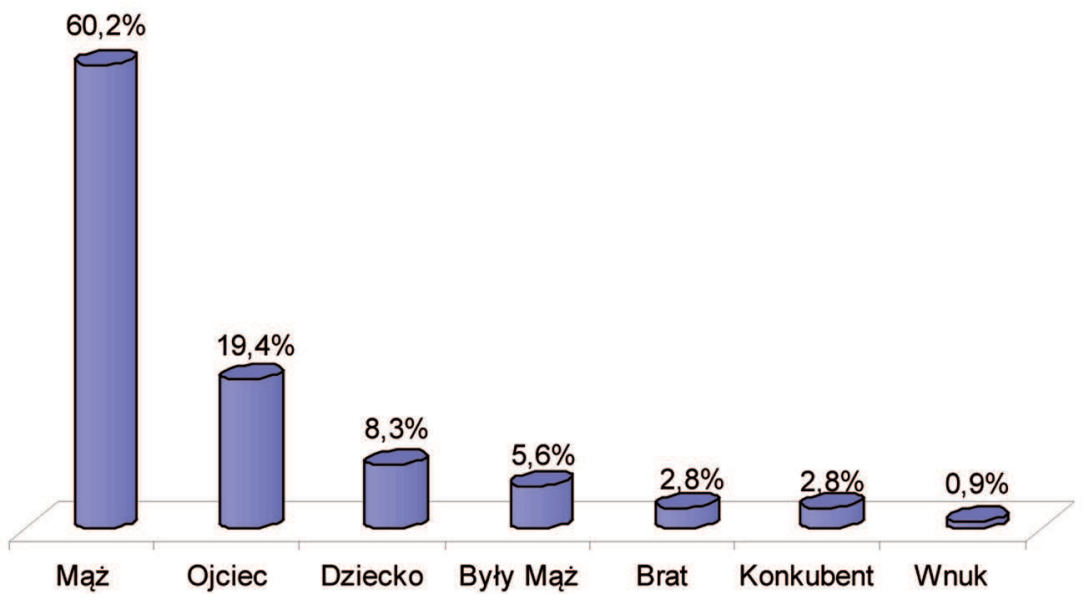

\section{CHARAKTERYSTYKA SPRAW}

Poniższa tabela przedstawia liczbę dzieci, jaka występowała w rodzinach doświadczonych przemocą domowa, jednakże nie wobec wszystkich tych dzieci przemoc ta miała miejsce. Zestawienia te mają na celu dogłębny opis rodzin objętych tą patologią. 
Tabela 10. Liczba dzieci w rodzinie.

\begin{tabular}{|c|c|c|}
\hline Liczba dzieci w rodzinie & $\begin{array}{c}\text { Liczba spraw } \\
\mathrm{N}=100\end{array}$ & $\%$ \\
\hline 1 & 32 & 32 \\
\hline 2 & 31 & 31 \\
\hline 3 & 22 & 22 \\
\hline 4 & 12 & 12 \\
\hline 5 i więcej & 3 & 3 \\
\hline
\end{tabular}

Co do liczby dzieci w rodzinach, w których występowała przemoc domowa porównywalny odsetek stanowiły rodziny z 1 i 2 dzieci. Najmniej przypadków znęcania się występowało w rodzinach z 5 dzieci i więcej, bo ich było najmniej. Struktura rodzin w Polsce dotkniętych przemocą nie różni się od innych rodzin, bowiem według danych GUS najmniej jest rodzin w Polsce z 4 dzieci i więcej ${ }^{1}$.

Wykres 4. Liczba dzieci w rodzinie.

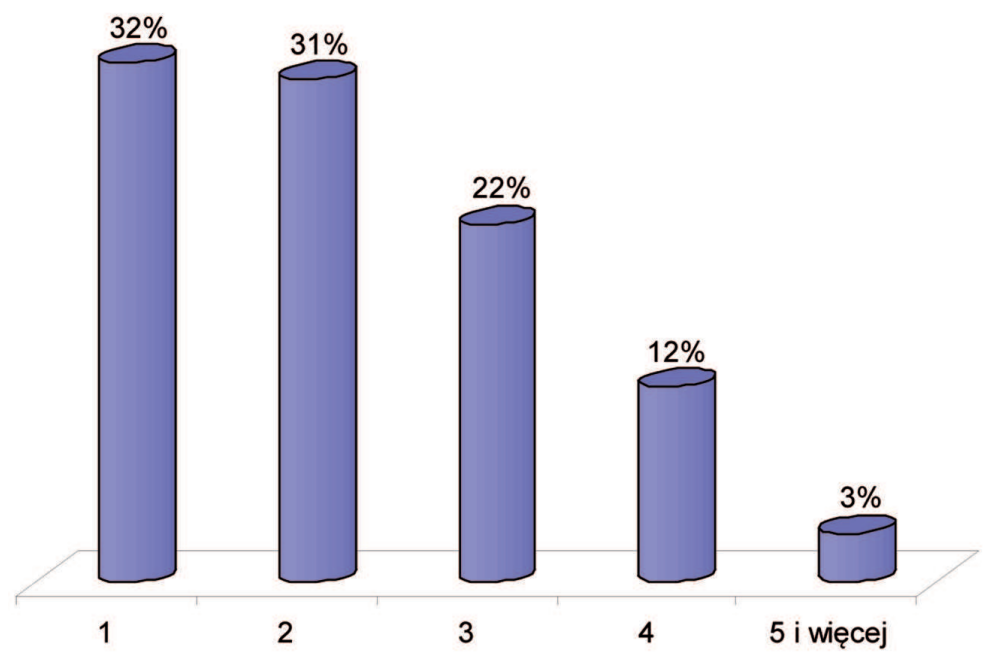

${ }^{1}$ Rocznik demograficzny 2008, s. 193 
Tabela 11. Osoba, która złożyła zawiadomienie o przestępstwie.

\begin{tabular}{|l|c|c|}
\hline $\begin{array}{c}\text { Kto złożył zawiadomienie } \\
\text { o przestępstwie? }\end{array}$ & $\begin{array}{c}\text { Liczba spraw } \\
\mathrm{N}=100\end{array}$ & $\%$ \\
\hline Żona sprawcy & 63 & 63 \\
\hline Matka / ojciec sprawcy & 11 & 11 \\
\hline Rodzeństwo ofiary & 6 & 6 \\
\hline Była żona sprawcy & 4 & 4 \\
\hline Konkubina sprawcy & 2 & 2 \\
\hline Dziecko sprawcy & 2 & 2 \\
\hline Pracownik opieki społecznej & 2 & 2 \\
\hline Kurator sądowy & 1 & 1 \\
\hline Policjanci & 1 & 1 \\
\hline Sasiedzi & 1 & 1 \\
\hline Inni & 4 & 4 \\
\hline Brak danych & 3 & 3 \\
\hline
\end{tabular}

W 63 przypadkach żona sprawcy była osoba, która złożyła zawiadomienie o popełnieniu przestępstwa stanowiącego art. 207 § 1 k.k. Z 11 zgłoszeniami spotkano się ze strony matki/ ojca sprawcy, zaś w 6 takich przypadkach osobami zgłaszającymi było jego rodzeństwo. 4 zawiadomienia o przestępstwie pochodziło od byłej żony sprawcy i tzw. „innych”, a w 3 sprawach nie uzyskano informacji w tym zakresie. Najmniej zgłoszeń przypadło ze strony: konkubiny, dziecka, pracownika opieki społecznej, kuratora sądowego, policjanta oraz sąsiada.

O złożeniu zawiadomienia o przestępstwie decydowały konkretne sytuacje. W każdym przypadku powodem zgłoszenia zawiadomienia o przestępstwie było stosowanie przemocy przez sprawcę. W tym w 94 przypadkach sprawca przemocy był pod wpływem alkoholu. W niewielu mniej sytuacjach, bo aż w 90 przypadkach zawiadomienie o przestępstwie w połączeniu z pierwszym czynnikiem stanowiło zagrożenie życia ofiary. Przez zagrożone życie ofiary w tej sytuacji rozumiano akty przemocy w czasie, których wystapiła realna i bezpośrednia groźba spowodowania ciężkiego uszczerbku na jej zdrowiu lub spowodowania 
utraty przez nią życia poprzez zastosowanie względem niej np. noża czy innego niebezpiecznego narzędzia. Z kolei 35 sytuacji, które m.in. wzmocniły decyzję o zgłoszeniu stanowiły obrażenia fizyczne, a 24 przypadki miały związek dodatkowo z konieczną pomocą medyczną. W najmniejszym stopniu czynnikiem powodującym złożenie zawiadomienia o popełnieniu przestępstwa $\mathrm{z}$ art. $207 \S 1$ k.k. lub wzmacniającym decyzję o jego zgłoszeniu były tzw. zdarzenia poważne. Przez zdarzenie poważne w tym ujęciu rozumiano akty przemocy wobec osób znajdujących się w szczególnej sytuacji, jak: ciąża, poruszanie się na wózku inwalidzkim, sparaliżowanych, w podeszłym wieku lub okresie niemowlęcym, których los w przypadku braku natychmiastowej interwencji mógłby skończyć się tragicznie.

W literaturze przedmiotu wyróżniamy świadków naocznych (bezpośrednich) i ze słuchu (pośrednich). Kryterium tego podziału jest oddalenie świadka od źródła wiadomości o czynie. Świadkowie naoczni to tacy, którzy osobiście rejestrowali zdarzenie własnymi zmysłami. Istotne tutaj jest, aby między świadkiem, a zdarzeniem nie było elementów pośrednich. Świadkowie ze słuchu czerpią swoją wiedzę o czynie od innej osoby lub osób. Sąd Najwyższy wprost formułuje tezę o dopuszczalności przesłuchania świadka ex auditu. „Ustawa nie zawiera zakazu przesłuchania świadka na okoliczności, o których dowiedział się od innych osób"2. Obowiązujący kodeks postępowania karnego nie wymaga, aby świadek był bezpośrednim obserwatorem zdarzenia czy faktów, które są przedmiotem jego zeznania. Świadkiem może więc być osoba, która ma tylko pośrednie wiadomości o zdarzeniu. W oparciu o powyższe należałoby traktować na równi wartość dowodową zeznań świadków naocznych z zeznaniami świadków ze słyszenia, jednakże spostrzeganie ludzi jest wybiórcze, a wiadomości powtarzane „z ust do ust” mogą być zniekształcone.

${ }^{2}$ Wyrok SN z 14 I 1926, VK 472/25, OSP 1926, poz. 238; Uchwała Izby Karnej SN z 11 XII 1926, VK 286/26, OSP 1927, poz. 201 
Tabela 12. Świadkowie zjawiska przemocy.

\begin{tabular}{|l|c|c|c|}
\hline $\begin{array}{c}\text { Świadkowie zjawiska } \\
\text { przemocy }\end{array}$ & $\begin{array}{c}\text { Świadkowie } \\
\text { naoczni } \\
\mathrm{N}=300\end{array}$ & $\begin{array}{c}\text { Świadkowie } \\
\text { ze słyszenia } \\
\mathrm{N}=47\end{array}$ & $\mathrm{~N}=347$ \\
\hline Sąsiedzi & 62 & 30 & 92 \\
\hline Policjanci & 64 & - & 64 \\
\hline Brat / siostra ofiary & 42 & 4 & 46 \\
\hline Dzieci & 39 & 1 & 40 \\
\hline Dziadkowie & 37 & 1 & 38 \\
\hline Inni krewni & 25 & 2 & 27 \\
\hline Znajomi rodziny & 9 & 9 & 18 \\
\hline Ojciec / matka sprawcy & 7 & - & 7 \\
\hline Brat / siostra sprawcy & 7 & - & 7 \\
\hline Kurator sądowy & 7 & - & 7 \\
\hline Ojciec / matka ofiary & 1 & - & 1 \\
\hline
\end{tabular}

Łącznie w badanych sprawach było 347 świadków. Z tego 300 osób stanowili świadkowie naoczni, a 47 - świadkowie ze słyszenia. Najczęściej świadkami naocznymi przemocy domowej byli policjanci i sąsiedzi. Policjanci często byli wzywani przez sąsiadów rodzin, w których była stosowana przemoc, także po przybyciu na interwencję byli bezpośrednimi świadkami aktów przemocy. Podobnie rzecz się miała odnośnie kuratorów sądowych. Przeważającą część świadków ze słyszenia także stanowili sąsiedzi. Suma członków rodzin w charakterze świadków wyniosła w przebadanych sprawach - 166. 
Wykres 5. Świadkowie zjawiska przemocy z podziałem na świadków naocznych i świadków ze słyszenia

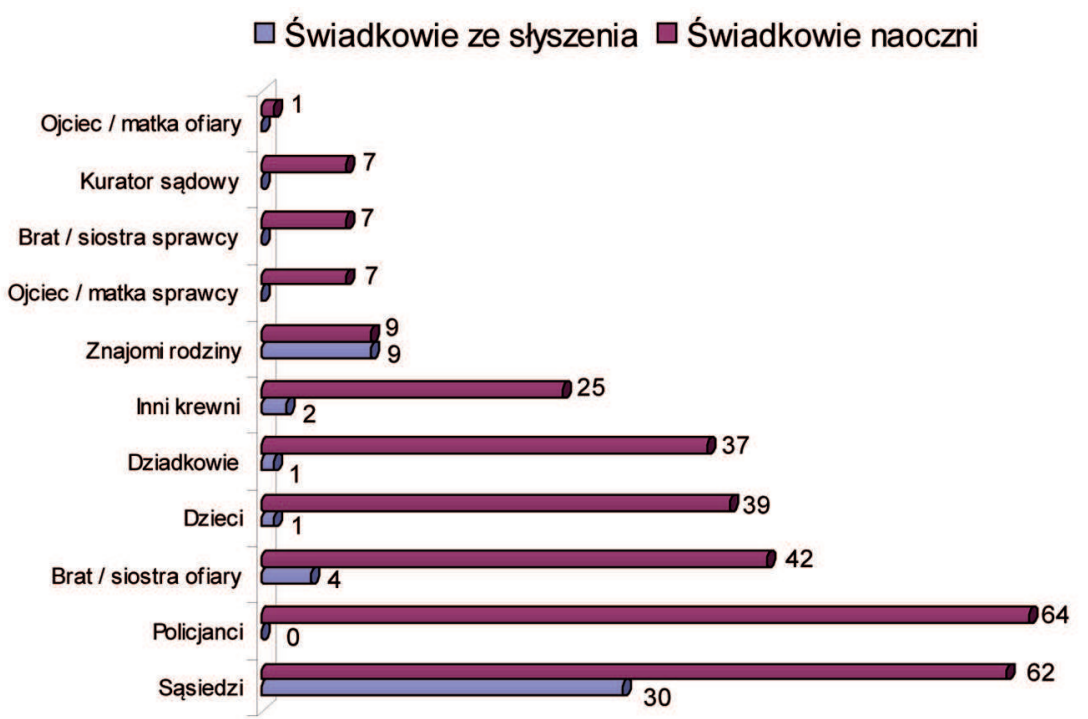

Tabela 13. Zachowanie świadków podczas aktu przemocy.

\begin{tabular}{|l|c|c|}
\hline $\begin{array}{c}\text { Jak zachowywali się świadkowie podczas } \\
\text { aktu przemocy? }\end{array}$ & $\begin{array}{c}\text { Świadkowie } \\
\text { naoczni } \\
\mathrm{N}=300\end{array}$ & $\%$ \\
\hline Interweniowali & 141 & 47 \\
\hline Pozostali bierni & 159 & 53 \\
\hline
\end{tabular}

Spośród 300 świadków naocznych mniej niż połowa zainterweniowała wskutek zetknięcia się ze zjawiskiem przemocy domowej. Najczęściej osobami interweniującymi byli: policjanci, członkowie najbliższej rodziny ofiary; jej dzieci, rodzeństwo, dziadkowie, a najrzadziej interweniowali sąsiedzi prawdopodobnie $\mathrm{z}$ obawy przed zemstą ze strony sprawcy przemocy. 
Wykres 6. Zachowanie świadków podczas aktu przemocy.

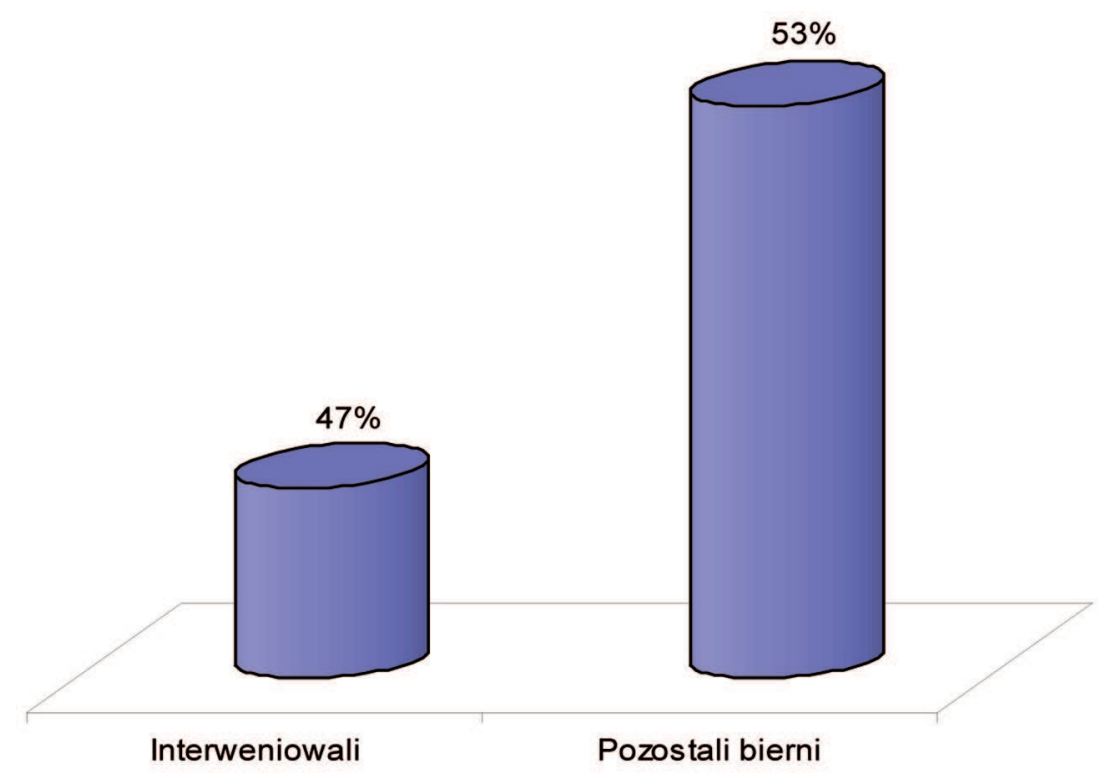

Niewątpliwie ważne jest ustalenie roli świadków w sprawie i ich wpływu na zapadły wyrok, tak więc tabela nr 11 prezentuje charakter zeznań świadków w sprawie.

Tabela 14. Charakter zeznań świadków w sprawie.

\begin{tabular}{|l|c|c|}
\hline $\begin{array}{c}\text { Jaki wpływ miały zeznania świadków na } \\
\text { zapadły wyrok w sprawie? }\end{array}$ & $\begin{array}{c}\text { Świadkowie } \\
\mathrm{N}=347\end{array}$ & $\%$ \\
\hline Obciążajace sprawcę & 339 & 97,7 \\
\hline Neutralne & 7 & 2,0 \\
\hline Usprawiedliwiające sprawcę & 1 & 0,3 \\
\hline
\end{tabular}

Odnośnie wpływu zeznań świadków na wyrok w sprawie można stwierdzić, iż największy odsetek, bo aż 97,7 dotyczył zeznań obciążających sprawcę. Tylko w 7 przypadkach wystapiły zeznania neutralne 
dla sprawcy, zaś zeznania usprawiedliwiające jego zachowanie wystapiły tylko w jednej sytuacji.

W polskim procesie karnym nie każdy ma prawo do odmowy składania zeznań czy odpowiedzi na pytanie. Z praw tych korzystają jedynie osoby uprawnione. Zgodnie $\mathrm{z}$ art. $182 \S 1$ k.p.k. osoba najbliższa dla oskarżonego może odmówić zeznań. Z kolei według art. $183 \S 1$ świadek może uchylić się od odpowiedzi na pytanie, jeżeli udzielenie odpowiedzi mogłoby narazić jego lub osobę dla niego najbliższą na odpowiedzialność za przestępstwo lub przestępstwo skarbowe. Zgodnie zaś z art. $115 \S 11$ k.k. przez osobę najbliższą rozumie się małżonka, wstępnego, zstępnego, rodzeństwo, powinowatego w tej samej linii lub stopniu, osobę pozostającą $\mathrm{w}$ stosunku przysposobienia oraz jej małżonka, a także osobę pozostającą we wspólnym pożyciu.

Tabela 15. Prawo do odmowy zeznań lub odpowiedzi na pytanie.

\begin{tabular}{|c|c|c|}
\hline $\begin{array}{c}\text { Liczba spraw, w których świadkowie } \\
\text { skorzystali z prawa odmowy zeznań lub } \\
\text { odpowiedzi na pytanie? }\end{array}$ & $\begin{array}{c}\text { Liczba spraw } \\
\mathrm{N}=100\end{array}$ & $\%$ \\
\hline Tak & 32 & 32 \\
\hline Nie & 68 & 68 \\
\hline
\end{tabular}

Z prawa do odmowy zeznań lub odpowiedzi na pytanie w toku sprawy skorzystały osoby uprawnione w 32 sprawach, a w tym było 45 osób.

W oparciu o przebadane akta można było stwierdzić, iż w większości spraw osoby uprawnione do odmowy zeznań nie skorzystały z tego prawa. Jedynie w 22 sprawach jedna osoba wykorzystała swoje uprawnienie, w ośmiu przypadkach po dwie osoby z niego skorzystało, a pojedyncze przypadki w tym zakresie dotyczą większej ilości członków rodziny (trzech do czterech osób).

Poniższe dane przedstawiają osoby, które skorzystały z prawa określonego w art. $182 \S 1$ k.p.k. oraz w art. $183 \S 1$ k.p.k. 
Tabela 16. Zestawienie informujące o tym kto korzystał z prawa odmowy zeznań lub odpowiedzi na pytanie.

\begin{tabular}{|l|c|c|}
\hline $\begin{array}{c}\text { Jeżeli w toku sprawy ktoś skorzystał } \\
\text { z prawa odmowy zeznań lub odpowiedzi } \\
\text { na pytanie to kto to był? }\end{array}$ & $\mathrm{N}=45$ & $\%$ \\
\hline Matka / ojciec sprawcy & 7 & 15,6 \\
\hline Brat / siostra sprawcy & 7 & 15,6 \\
\hline Ofiara - dziecko & 8 & 17,8 \\
\hline Brat / siostra ofiary & 9 & 20,0 \\
\hline Babcia / dziadek & 9 & 20,0 \\
\hline Ofiara - dorosły & 3 & 6,6 \\
\hline Matka / ojciec ofiary & 1 & 2,2 \\
\hline Żona sprawcy & 1 & 2,2 \\
\hline
\end{tabular}

Jak wynika z analizy akt najczęściej z prawa do odmowy zeznań lub odpowiedzi na pytanie w toku sprawy skorzystali brat/ siostra ofiary, babcia/ dziadek oraz dziecko będące ofiarą. Pojedyncze przypadki w tym zakresie dotyczyły matki/ ojca ofiary oraz żony sprawcy. 
Wykres 7. Zestawienie informujące o tym kto korzystał z prawa odmowy zeznań lub odpowiedzi na pytanie.

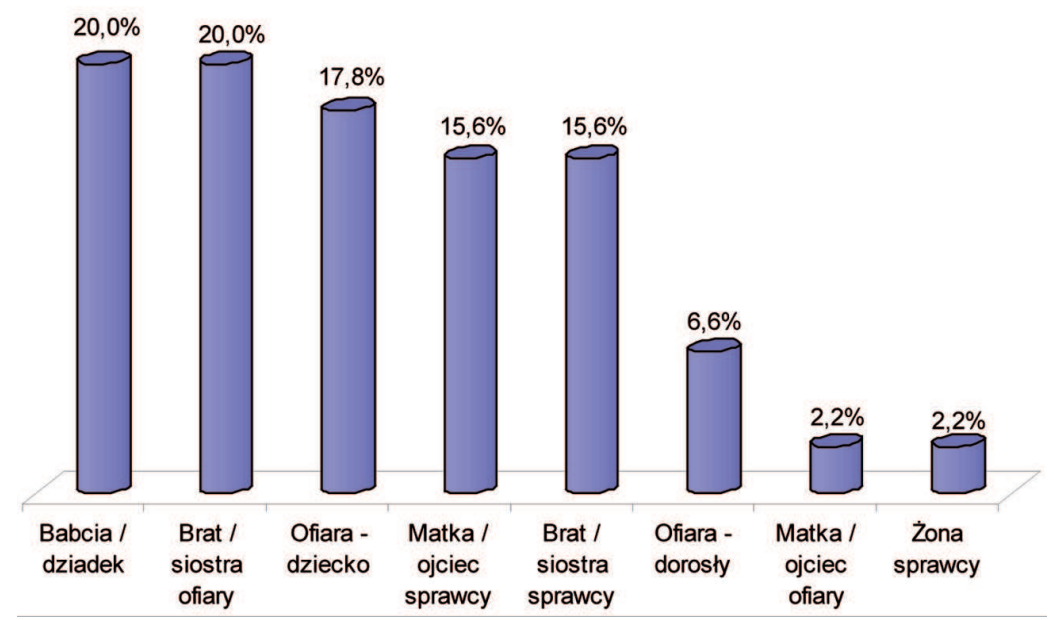

Przy ustalaniu wyroku niezmiernie istotne jest uwzględnienie wszystkich okoliczności łagodzących i obciążających w sprawie.

Tabela 17. Okoliczności łagodzące w sprawie.

\begin{tabular}{|l|c|c|}
\hline \multicolumn{1}{|c|}{$\begin{array}{c}\text { Jeżeli występowały okoliczności } \\
\text { łagodzące w sprawie to jakie? }\end{array}$} & $\begin{array}{c}\text { Liczba spraw } \\
\text { N = 100 }\end{array}$ & $\%$ \\
\hline Brak uprzedniej karalności & 22 & 22 \\
\hline Krótki okres czynu przestępczego & 8 & 8 \\
\hline Inne & 8 & 8 \\
\hline Stan afektu & 2 & 2 \\
\hline Choroba psychiczna & 1 & 1 \\
\hline Brak okoliczności łagodzących & 65 & 65 \\
\hline
\end{tabular}

UWAGA: Procenty nie sumują się do 100\%, gdyż istnieje możliwość występowania kilku okoliczności łagodzących w jednej sprawie 
W 65 sprawach nie spotkano się z okolicznościami łagodzącymi wobec sprawcy. W 22 przypadkach okolicznościami łagodzącymi był brak uprzedniej karalności, zaś w 8 sytuacjach spotkano się z krótkim okresem czynu przestępczego oraz z tzw. , innymi”. Do tzw. „, innych” sędzia zaliczył: młody wiek sprawcy, brak zdolności pokierowania swoim postępowaniem, działanie sprawcy w wyniku impulsu na tle chorobowym, brak działania pod wpływem z góry ustalonego planu, prowokujące zachowanie żony, jej skłonności do alkoholu i do zdrady. W dwóch sytuacjach stwierdzono stan afektu, zaś w jednym przypadku wykryto chorobę psychiczna.

Wykres 8. Okoliczności łagodzące w sprawie.

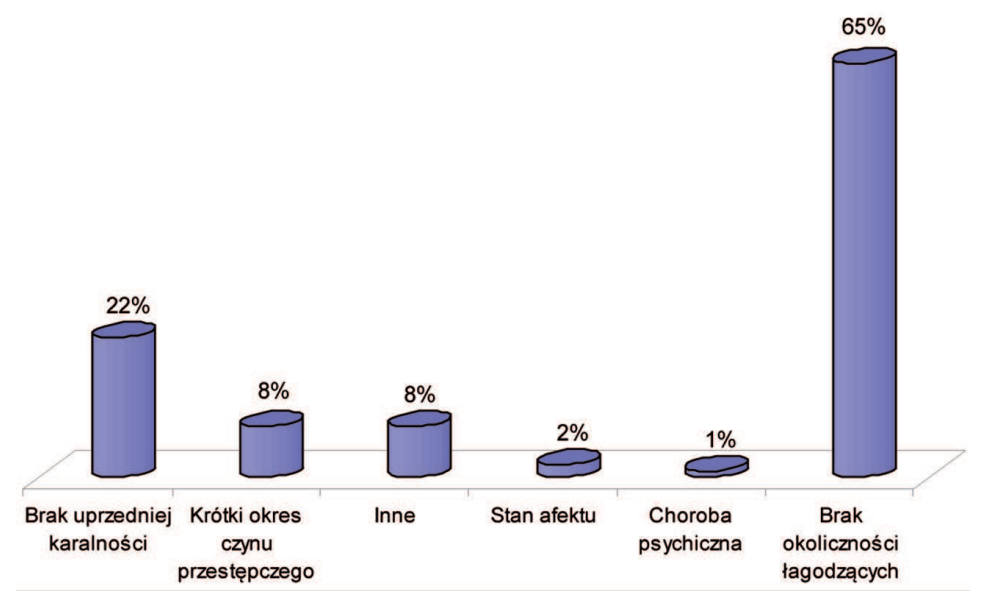

Tabela 18. Rodzaj okoliczności obciążających sprawcę.

\begin{tabular}{|l|c|c|}
\hline \multicolumn{1}{|c|}{$\begin{array}{c}\text { Jeżeli występowały okoliczności } \\
\text { obciążąące w sprawie to jakie? }\end{array}$} & $\begin{array}{c}\text { Liczba spraw } \\
\mathrm{N}=100\end{array}$ & $\%$ \\
\hline Nadużywanie alkoholu & 91 & 91 \\
\hline Narkotyki & 2 & 2 \\
\hline Częstotliwość znęcania się & 7 & 7 \\
\hline Inne & 25 & 25 \\
\hline
\end{tabular}


UWAGA: Procenty nie sumują się do 100\%, gdyż istnieje możliwość występowania kilku okoliczności obciążających w jednej sprawie.

Najczęstszą okolicznością obciążająca w sprawie było nadużywanie alkoholu przez sprawcę. Miało ono miejsce aż w 91 przypadkach. 25 wyniosła suma tzw. „innych” okoliczności obciążających. Do nich sędzia zaliczył: wysoki stopień agresywności sprawcy, drastyczność czynów, uprzednią karalność za ten sam czyn. W 7 sprawach stwierdzono dużą częstotliwość przestępstwa znęcania się, a w 2 przypadkach sprawca zażywał narkotyki.

Wykres 9. Rodzaj okoliczności obciążających w sprawie.

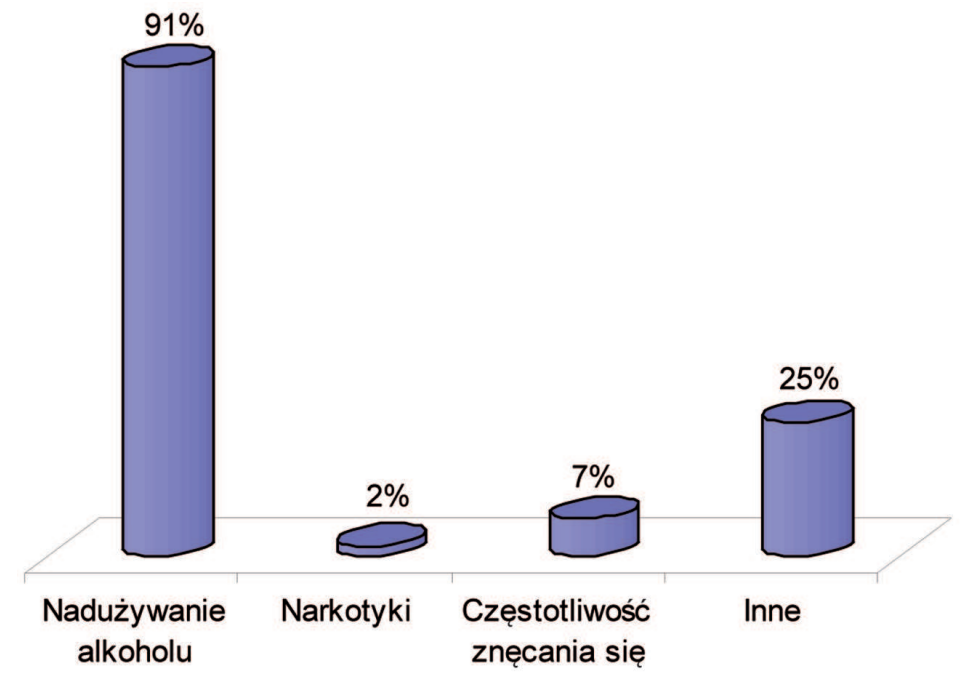


Tabela 19. Reakcja policji na zgłoszenie.

\begin{tabular}{|l|c|c|}
\hline \multicolumn{1}{|c|}{ Co zrobiła policja aby pomóc ofierze? } & $\begin{array}{c}\text { Liczba spraw } \\
\mathrm{N}=100\end{array}$ & $\%$ \\
\hline Przyjęli zgłoszenie & 99 & 99 \\
\hline $\begin{array}{l}\text { Udzielili informacji o pomocy prawnej, } \\
\text { placówce specjalistycznej }\end{array}$ & 92 & 92 \\
\hline Zapewnili ochronę, zatrzymali sprawcę & 45 & 45 \\
\hline $\begin{array}{l}\text { Zasugerowali kontakt z placówką } \\
\text { specjalistyczną }\end{array}$ & 1 & 1 \\
\hline
\end{tabular}

UWAGA: Procenty nie sumują się do $100 \%$, gdyż istnieje możliwość występowania kilku różnych reakcji policji na zgłoszenie w jednej sprawie.

W 99 przypadkach policja przyjęła zawiadomienie o przestępstwie $\mathrm{z}$ art. $207 \S 1$ k.k., jednocześnie udzielając $\mathrm{w} 92$ sytuacjach osobie zgłaszającej informacji o pomocy prawnej, placówce specjalistycznej. Ponadto $\mathrm{w} 45$ przypadkach funkcjonariusze policji zapewnili ofierze ochronę, zatrzymali sprawcę i jednokrotnie zasugerowali kontakt z placówką specjalistyczną. Reakcja policja na złożone zawiadomienie o popełnieniu przestępstwa znęcania się jest widoczna w 99\%, gdyż spotkano się $\mathrm{w}$ trakcie przeprowadzanych badań z jednym przypadkiem zgłoszenia ze strony funkcjonariusza policji.

Tabela 20. Liczba wcześniejszych interwencji policji w danej rodzinie.

\begin{tabular}{|l|c|c|}
\hline $\begin{array}{c}\text { Liczba wcześniejszych interwencji policji } \\
\text { w rodzinie }\end{array}$ & $\begin{array}{c}\text { Liczba spraw } \\
\mathrm{N}=100\end{array}$ & $\%$ \\
\hline Wielokrotnie & 76 & 76 \\
\hline Uprzednio jednokrotnie & 13 & 13 \\
\hline Brak wcześniejszych interwencji & 11 & 11 \\
\hline
\end{tabular}


Przed złożeniem zawiadomienia o popełnieniu przestępstwa stanowiącego art. $207 \S 1$ k.k. policja interweniowało uprzednio w danej rodzinie jeden raz w 13 przypadkach. W większości przebadanych spraw kobiety zdecydowały się na złożenie zawiadomienia o przestępstwie kiedy było wiele interwencji i nie odnosiły one skutku, a one bały się i poniosły uszczerbki na zdrowiu. Tylko w 11 sprawach nie spotkano się z wcześniejszymi interwencjami.

Wykres 10. Liczba wcześniejszych interwencji policji w rodzinie.

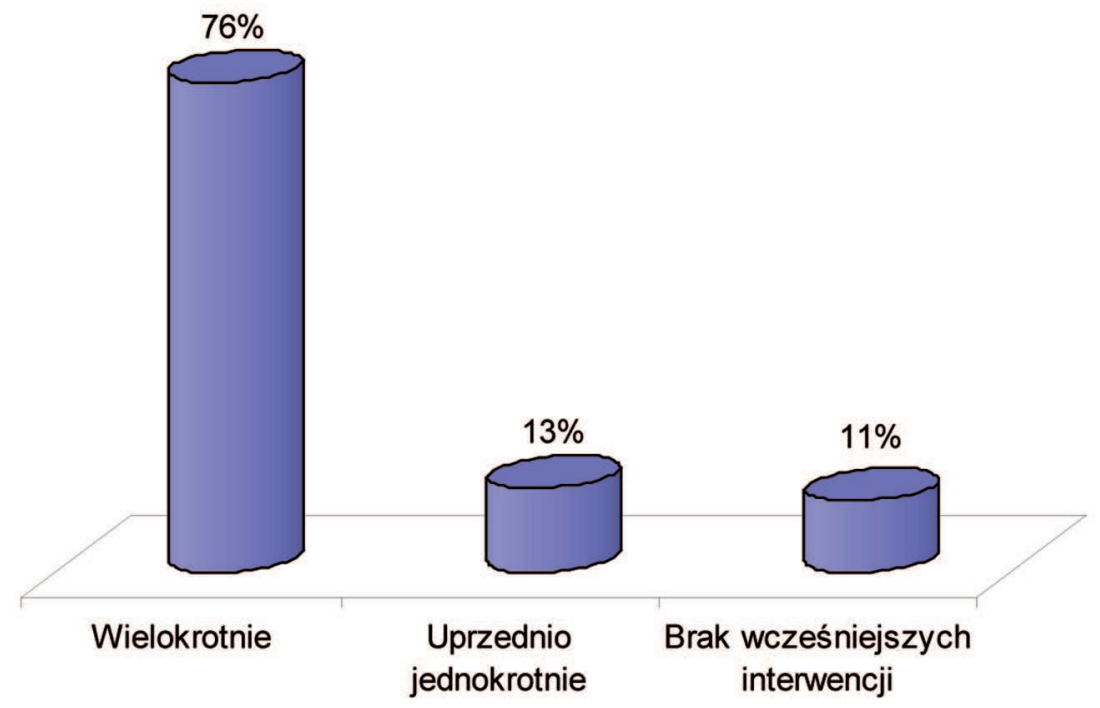

Analizując czynniki, które mogły wpłynąć na fakt zgłoszenia zdarzenia na policję, uwzględniono m.in. takie cechy, jak: miejsce popełnienia przestępstwa i częstotliwość czynu. 
Tabela 21. Miejsce popełnienia aktu przemocy.

\begin{tabular}{|l|c|c|}
\hline \multicolumn{1}{|c|}{ Miejsce popełnienia aktu przemocy } & $\begin{array}{c}\text { Liczba spraw } \\
\mathrm{N}=100\end{array}$ & $\%$ \\
\hline Miasto & 58 & 58 \\
\hline Wieś & 42 & 42 \\
\hline
\end{tabular}

Miejscem popełnienia aktów przemocy w $58 \%$ było miasto. Można przypuszczać, iż wyższy odsetek zgłoszeń przemocy domowej występujący w mieście wynika $\mathrm{z}$ większej świadomości ofiar co do swoich praw i możliwości (chociażby ochrony ze strony różnych placówek). Styl życia wraz ze sposobem funkcjonowania osób zamieszkałych w miastach charakteryzuje się znacznie większą aktywnością, a to sprzyja zwiększeniu ryzyka stania się ofiarą przestępstwa. Według wyników IVAWS (Międzynarodowego Programu Badań nad Przemocą wobec Kobiet) dzięki większej świadomości, ale również łatwiejszemu (bliższemu) dostępu do policji potwierdza się przypuszczenie, że w miastach, a zwłaszcza w tych dużych, częściej występuje narażenie na przemoc ${ }^{3}$.

${ }^{3}$ B. Gruszczyńska, Przemoc wobec kobiet w Polsce, Aspekty prawnokryminologiczne, Warszawa 2007, s. 84. 
Wykres 11. Miejsce popełnienia aktu przemocy.

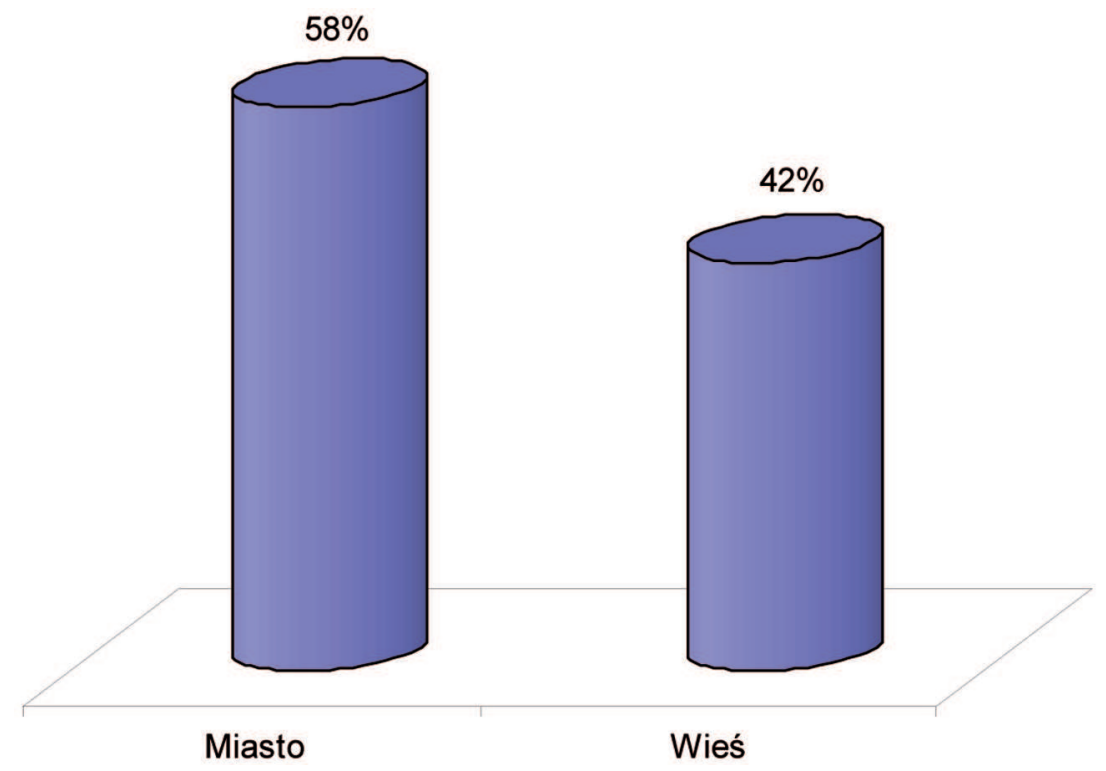

Tabela 22. Częstotliwość czynu.

\begin{tabular}{|l|c|c|}
\hline \multicolumn{1}{|c|}{ Częstotliwość czynu } & $\begin{array}{c}\text { Liczba spraw } \\
\mathrm{N}=100\end{array}$ & $\%$ \\
\hline Po raz pierwszy & 1 & 1 \\
\hline Po raz drugi & - & - \\
\hline Wielokrotnie & 99 & 99 \\
\hline
\end{tabular}

Co do pytania dotyczącego częstotliwości czynu, aż 99\% stanowiła jego wielokrotność, także niewątpliwie mogło to być w znacznym stopniu czynnikiem wzmacniającym decyzję o zgłoszenia przestępstwa przez ofiary. W $1 \%$ odnotowano popełnienie czynu po raz pierwszy. 
Tabela 23. Wyrok w sprawie.

\begin{tabular}{|l|c|c|}
\hline \multicolumn{1}{|c|}{ Jaki zapadł wyrok w sprawie? } & $\begin{array}{c}\text { Liczba spraw } \\
\mathrm{N}=100\end{array}$ & $\% 1$ \\
\hline $\begin{array}{l}\text { Pozbawienie wolności z warunkowym } \\
\text { zawieszeniem wraz z zobowiązaniami dla } \\
\text { sprawcy z art. } 72 \S 1 \text { k.k. }\end{array}$ & 61 & 13 \\
\hline Ograniczenie wolności & 13 & 8 \\
\hline Bezwzględne pozbawienie wolności & 8 & 6 \\
\hline Zawieszenie postępowania & 6 & 3 \\
\hline $\begin{array}{l}\text { Ograniczenie wolności z zawieszeniem } \\
\text { wraz z zobowiązaniami dla sprawcy } \\
\text { z art. 72 §1 k.k. }\end{array}$ & 3 & 9 \\
\hline Inne & 9 & \\
\hline
\end{tabular}

W oparciu o badania ustalono, iż najczęstszym z wyroków względem sprawców dopuszczających się przestępstwa określonego w art. 207 § 1 k.k. było pozbawienie wolności z warunkowym zawieszeniem w połaczeniu z zobowiązaniami określonymi w art. $72 \S 1$ k.k. W statystykach sądowych także ta kara najczęściej występuje na skutek przestępstwa znęcania się. Dane te zostały przedstawione w podsumowaniu części teoretycznej. Ograniczenie wolności wobec sprawców miało miejsce w kilkunastu przypadkach, zaś w kategorii określonej jako inne mieściły się sprawy zakończone: odwieszeniem wymierzonej wcześniej kary sprawcy z tego samego tytułu, zastosowaniem środka zabezpieczającego w postaci umieszczenia oskarżonego z zamkniętym zakładzie leczenia odwykowego, umieszczeniem sprawcy w odpowiednim zakładzie psychiatrycznym oraz umorzeniem postępowania z uwagi na śmierć oskarżonego. Bezwzględne pozbawienie wolności wystapiło tylko w kilku sytuacjach, a sporadycznie wystapiły przypadki zawieszenia postępowania i ograniczenia wolności z zawieszeniem wraz z zobowiązaniami dla sprawcy $\mathrm{z}$ art. $72 \S 1$ k.k. 
Mediacja jest ważnym narzędziem i sposobem rozwiązywania sporów. Istota jej jest osiagnięcie konsensusu pomiędzy pokrzywdzonym, a sprawcą czynu przestępnego. W literaturze przedmiotu $\mathrm{z}$ tego zakresu często spotyka się z postulatem o częste stosowanie postępowania mediacyjnego przez sądy.

Tabela 24. Liczba postępowań mediacyjnych.

\begin{tabular}{|c|c|c|}
\hline $\begin{array}{c}\text { Czy w sprawie występowało } \\
\text { postępowanie mediacyjne? }\end{array}$ & $\mathrm{N}=100$ & $\%$ \\
\hline Tak & 12 & 12 \\
\hline Nie & 88 & 88 \\
\hline
\end{tabular}

W toku analizowanych spraw stwierdzono 12 postępowań mediacyjnych. Były one przeprowadzane z inicjatywy żon sprawców, które wierzyły w ich poprawę i nie chciały dla nich ciężkich dolegliwości karnych z tytułu znęcania się nad rodziną, jednakże skutek mediacji był mizerny, bowiem de facto niczego nie zmienił.

Tabela 25. Wymiar kary bezwzględnego pozbawienia wolności.

\begin{tabular}{|l|c|c|}
\hline $\begin{array}{c}\text { Wymiar kary bezwzględnego } \\
\text { pozbawienia wolności }\end{array}$ & $\begin{array}{c}\text { Kary bezwzg. } \\
\text { pozbawienia } \\
\text { wolności } \\
\text { N = }\end{array}$ & $\%$ \\
\hline Poniżej roku & 1 & 12,5 \\
\hline Rok & 2 & 25 \\
\hline Powyżej roku do 2 lat & 3 & 37,5 \\
\hline Powyżej 2 do 3 lat & 2 & 25 \\
\hline
\end{tabular}

W oparciu o analizę akt sądowych wykazano, iż Sąd w niewielu przypadkach, bo zaledwie 8 wymierzył sprawcom karę bezwzględnego pozbawienia wolności. Nie stosowano w większej liczbie przypadków bezwzględnego pozbawienia wolności z uwagi na: sylwetkę sprawcy, 
okoliczności łagodzące w sprawie oraz pozytywną prognozą co do resocjalizacji sprawców.

\section{PODSUMOWANIE}

Sprawy z zakresu przemocy domowej są często powodowane konfliktami rodzinnymi, prowokacja jednej ze stron, ale interesem osoby pokrzywdzonej nie zawsze jest bezwzględne pozbawienie sprawcy wolności, co z pewnością wpływa na liczbę przestępstw nieujawnionych.

W oparciu o przebadane sprawy stwierdzono, że zarówno sprawca przemocy, jak i ofiara dorosła pozostawali ze sobą w bliskich związkach.

Badania wykazały, że dziecko było głównie ofiarą przemocy w rodzinach, w których alkohol jest nadużywany oraz tam gdzie występuja liczne awantury. Poza tym dziecko było głównie atakowane wtedy, gdy bezpośredni atak był wymierzony w kierunku matki, a dzieci stawały w jej obronie. Tylko w 32 sprawach atak był wymierzony jedynie w stosunku do dziecka. Powszechną reakcją dziecka na doznaną przemoc był strach, któremu towarzyszył: krzyk, płacz oraz wzywanie pomocy.

Statystyki policyjne są obszerne odnośnie interwencji domowych na skutek przemocy domowej, jednakże Sądy rejestrują tylko przypadki prawomocnie skazanych sprawców, a dużo spraw jest umarzanych. Poza tym sprawcy przemocy otrzymują często dozór kuratora i dla niektórych „problem na tym się kończy”.

Warto ponadto zauważyć, że najczęściej świadkami przemocy są sąsiedzi, którzy jednak często milczą z powodu strachu przed sprawcą przemocy, a to także w dużym stopniu powoduje braki dowodowe w przeprowadzanych postępowaniach, co wpływa na korzyść sprawców przemocy domowej.

Często brak jest konkretnych działań ze strony Wymiaru Sprawiedliwości, szczególnie separacji sprawcy od swych ofiar, gdyż w praktyce sporadycznie Sąd orzeka taką sankcję względem sprawcy przemocy, a z uwagi na to ofiary czują się bezradne.

Osoby krzywdzone w dzieciństwie zwiększaja grupę ludzi, która nie radzi sobie w życiu, stwarza problemy, a nawet zagraża innym, bowiem 
jednostki takie nie potrafią poradzić sobie w codziennym funkcjonowaniu inaczej, jak poprzez wyładowanie agresji. Na taki stan rzeczy wpływa także niskie wykształcenie, brak dialogu rodzinnego, a wzywanie policji na interwencję przez ofiary bywa dyshonorem. Niewatpliwie przydałoby się poszerzyć badania odnośnie psychopatologicznych właściwości sprawców, aby skutecznie zmniejszyć ich ilość.

\section{BIBLIOGRAFIA}

Gruszczyńska B., Przemoc wobec kobiet w Polsce, Aspekty prawno kryminologiczne, Warszawa 2007.

Rocznik demograficzny 2008.

Wyrok SN z 14 I 1926, VK 472/25, OSP 1926, poz. 238; Uchwała Izby Karnej SN z 11 XII 1926, VK 286/26, OSP 1927, poz. 201. 